NOTE

\title{
The initial journey of an Endangered penguin: implications for seabird conservation
}

\author{
Richard B. Sherley ${ }^{1,2,3, *}$, Katrin Ludynia ${ }^{1,2}$, Tarron Lamont ${ }^{4}$, Jean-Paul Roux ${ }^{1,5}$, \\ Robert J. M. Crawford ${ }^{1,4}$, Les G. Underhill ${ }^{1,2}$ \\ ${ }^{1}$ Animal Demography Unit, Department of Biological Sciences, and ${ }^{2}$ Marine Research Institute, University of Cape Town, \\ Rondebosch 7701, South Africa \\ ${ }^{3}$ Bristol Conservation and Science Foundation, Bristol Zoo Gardens, Bristol BS8 3HA, UK \\ ${ }^{4}$ Oceans and Coasts, Department of Environmental Affairs, Rogge Bay 8012, South Africa \\ ${ }^{5}$ Ministry of Fisheries and Marine Resources, PO Box 15 394, Lüderitz, Namibia
}

\begin{abstract}
Seabirds can disperse widely in search of prey, especially during non-breeding periods. Conservation measures predominately focus on protecting breeding colonies, but juvenile survival and recruitment can have critical impacts on population dynamics. We report the first deployment of satellite transmitters to track the dispersal of fledgling African penguins Spheniscus demersus, a step towards determining the at-sea behaviour of post-fledging birds and identifying the key non-breeding habitats for this species. Five hand-reared fledglings dispersed from their release sites in the Western Cape, South Africa, in a north-westerly direction. Birds moved $>100 \mathrm{~km}$ within $6 \mathrm{~d}$ and reached a mean distance of $>1000 \mathrm{~km}$ from their release sites. Two key foraging areas were identified in regions of high and reliable primary productivity, one around Swakopmund, Namibia, and one north of Lambert's Bay, South Africa. Neither site has protected status, underlining the importance of adaptive strategies to preserve key foraging hotspots and the need for further information on post-fledging dispersal to improve seabird conservation.
\end{abstract}

KEY WORDS: Juvenile dispersal · Seabird conservation · Foraging hotspots · Important bird areas · Satellite tracking $\cdot$ Benguela current $\cdot$ Fledglings

\section{INTRODUCTION}

Species feeding in the upper trophic levels of marine food webs play important roles in ecosystem functioning, but often have poor global conservation statuses (Myers \& Worm 2003, Croxall et al. 2012, Lewison et al. 2012). Many range over large areas and cross international boundaries throughout their lives (e.g. González-Solís et al. 2007), making it difficult to develop site-specific conservation measures of sufficient scale (Yorio 2009). However, many studies tracking the movements of marine top predators (e.g. Hart \& Hyrenbach 2009) suggest that they often make use of specific ecological hotspots (e.g. Fort et al. 2012). Where such areas exist, it is important that they be identified and managed appropriately. Although post-fledging seabirds have been tracked (Clarke et al. 2003, Votier et al. 2011), studies on seabirds at sea focus predominately on breeding and post-breeding adults (Lewison et al. 2012). The at-sea behaviour of juveniles remains severely understudied (Croxall et al. 2012, Lewison et al. 2012) despite the fact that their survival and recruitment into breeding populations can have critical impacts on population dynamics (e.g. Votier et al. 2008). 
In the Benguela ecosystem of southern Africa, natural and anthropogenic factors have caused large population decreases in several endemic seabird species (Crawford et al. 2008). Heavy exploitation of lower trophic level fish precipitated a switch to poorquality prey in Namibia (Ludynia et al. 2010), while a change in the relative abundance of adult sardine Sardinops sagax and anchovy Engraulis encrasicolus during the late-1990s and early-2000s (van der Lingen et al. 2006) has resulted in a spatial mismatch between the majority of the spawner stocks and the foraging ranges of breeding seabirds on South Africa's west coast (e.g. Grémillet et al. 2008). African penguins Spheniscus demersus feed predominantly on anchovy and sardine and rely on the prey available close to their colonies to breed successfully (Sherley et al. 2013). These 2 factors make the population vulnerable to changes in the distribution or availability of their prey, and the species is currently Endangered following a decline in South Africa of $>60 \%$ between 2001 and 2009 (Crawford et al. 2011).

The deteriorating conservation status of this species led to temporary prohibitions on purse-seine fishing around some breeding colonies to test whether closures could improve local prey availability to seabirds (Crawford et al. 2011). However, African penguins can move over 100s of kilometres when not breeding (Randall et al. 1987), and little is known about the habitat use of fledglings and nonbreeding birds (but see Barham et al. 2006), either in relation to the distribution of their prey or in relation to protected areas. Understanding the drivers of dispersal behaviour and foraging-habitat choice in nonbreeding birds is thus important for guiding conservation strategies (Lewison et al. 2012). We report the first deployment of satellite transmitters (or platform terminal transmitters, PTTs) on fledgling African penguins. During 2011, 5 partially hand-reared chicks were equipped with PTTs, released from the vicinity of breeding colonies and tracked during their initial dispersal as a first step in determining the atsea behaviour of post-fledging birds and identifying the key habitats used by this species outside of the breeding season.

\section{MATERIALS AND METHODS}

Abandoned African penguin chicks have periodically been removed from South African colonies and taken to the Southern African Foundation for the Conservation of Coastal Birds (SANCCOB; $33^{\circ} 50^{\prime} \mathrm{S}, 18^{\circ} 29^{\prime} \mathrm{E}$ ) to be partially hand-reared (Barham et al. 2008). Following blood, waterproofing and body condition evaluations, they are released as fledglings (e.g. Table 1). Hand-reared fledglings survive at least as well as their naturally reared counterparts, are released at above average mass and have experience swimming prior to release (Barham et al. 2008). Given the potential for deleterious effects of the PTTs (Wilson et al. 2004) and the need to balance knowledge acquisition with ethical and conservation concerns, we selected hand-reared chicks (rather than chicks fledged naturally at a breeding colony) for PTT deployment. Blood samples and weights of several candidate birds were taken ca. every $7 \mathrm{~d}$, and 5 individuals were selected that satisfied SANCCOB's conditions for release and exceeded the mean fledging mass at Robben Island in 2004 (2830 g), a year of aboveaverage chick growth (Sherley 2010; Table 1). Two birds originally hatched at Robben Island $\left(33^{\circ} 48^{\prime} \mathrm{S}\right.$, $18^{\circ} 22^{\prime} \mathrm{E}$; Fig. 1), 2 at Boulders Beach (341' $\mathrm{S}$, $18^{\circ} 27^{\prime} \mathrm{E}$ ) and 1 at SANCCOB from an egg of wild origin (Table 1).

A few days prior to release (see Table 2), we attached a PTT (KiwiSat ${ }^{\circledR} 202,60 \times 27 \times 17$ mm, 32 g; Sirtrack) to the feathers of each bird with waterproof Tesa ${ }^{\circledR}$ tape, cyanoacrylate glue (Loctite ${ }^{\circledR}$ 401) and plastic cable ties. The PTTs were attached to the centre of the

Table 1. Spheniscus demersus. Pre-release information for the 5 fledgling African penguins tracked in 2011. Mass, head length, haematocrit and total serum protein were measured for each bird 3 (PTT 105335) or $4 \mathrm{~d}$ (all other birds) prior to the release date (see Table 2). S: SANCCOB ( $\left.33^{\circ} 50^{\prime} \mathrm{S}, 18^{\circ} 29^{\prime} \mathrm{E}\right)$; BB: Boulders Beach $\left(34^{\circ} 11^{\prime} \mathrm{S}, 1^{\circ} 27^{\prime} \mathrm{E}\right)$; RI: Robben Island (see Fig. 1); SP: Stony Point (see Fig. 1)

\begin{tabular}{|c|c|c|c|c|c|c|}
\hline PTT ID & $\begin{array}{l}\text { Hatching location } \\
\text { (origin) }\end{array}$ & $\begin{array}{l}\text { Release } \\
\text { location }\end{array}$ & $\begin{array}{l}\text { Mass } \\
(\mathrm{g})\end{array}$ & $\begin{array}{l}\text { Head length } \\
(\mathrm{mm})\end{array}$ & $\begin{array}{c}\text { Hematocrit } \\
(\%)\end{array}$ & $\begin{array}{l}\text { Total serum protein } \\
\qquad\left(\mathrm{g} 100 \mathrm{ml}^{-1}\right)\end{array}$ \\
\hline 105335 & $\mathrm{~S}$ & RI & 3220 & 120.6 & 43 & 5.0 \\
\hline 105336 & BB & RI & 3180 & 119.5 & 44 & 5.4 \\
\hline 105337 & $\mathrm{BB}$ & RI & 3040 & 124.4 & 47 & 6.4 \\
\hline 105338 & RI & $\mathrm{SP}$ & 2950 & 115.7 & 35 & 4.2 \\
\hline 105339 & RI & SP & 3200 & 117.9 & 31 & 4.6 \\
\hline
\end{tabular}



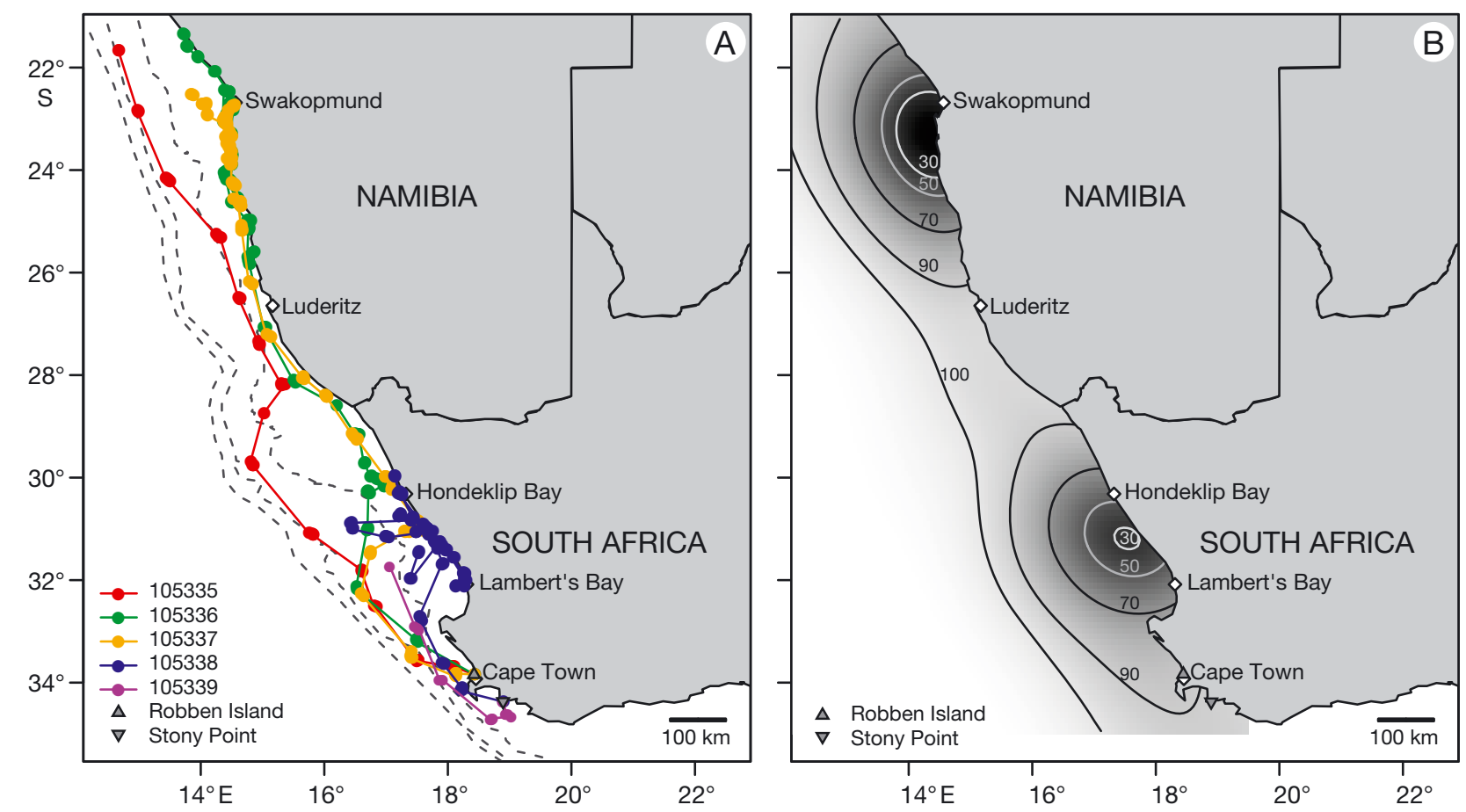

Fig. 1. Spheniscus demersus. Southern Africa showing (A) the paths of 5 African penguin fledglings tracked using satellite transmitters (PTT ID Numbers 105335 to 105339$)$ from release locations at Robben Island $(\triangle)$ or Stony Point $(\nabla)$ in relation to the 200, 500 and $1000 \mathrm{~m}$ isobaths (dashed lines) (Smith \& Sandwell 1997) and (B) the percentage volume contours (PVCs) from kernel density estimation of the location data. The 30, 50, 70, 90 and $100 \%$ PVCs are shown

back, caudal to the flippers and as far aft as possible to allow the birds to walk unimpeded by the antenna (prior to release and if they made landfall) and not to impair preening. To reduce drag, time-depth recorders and flipper bands were not used. Each bird was allowed to swim in a pool with the device attached for ca. $1 \mathrm{~h}$ on at least $3 \mathrm{~d}$ before release. Three of the fledglings (PTTs 105335, 105336 and 105337) were released at Robben Island and 2 (PTTs 105338 and 105339) at Stony Point ( $34^{\circ} 22^{\prime} \mathrm{S}, 18^{\circ} 53^{\prime} \mathrm{E}_{\text {; Fig. }}$ ).

The PTTs were programmed to transmit every $45 \mathrm{~s}$ between 0100 and 0459 h GMT every second day from 1 June 2011. Location data with specified levels of accuracy (location classes, LC) were obtained from the ARGOS system (www.argos-system.org). Low quality positions (LC A, B, or Z) were excluded, and an iterative filter was applied to remove unlikely locations based on abrupt changes of direction (Freitas et al. 2008) and a maximum travel speed of $6.6 \mathrm{~km} \mathrm{~h}^{-1}$ (Wilson 1985). Validated positions were used to calculate approximate travel distances. One fix per bird per day (best LC or closest to midnight) was used to produce kernel density estimates (bandwidth $=0.2$ ) to illustrate percentage volume contours (PVC), with the $50 \%$ PVC taken to indicate probable foraging areas (Wood et al. 2000). Analyses were conducted using the 'spatstat' and 'argosfilter' packages for R (Version 2.14.1; R Development Core Team 2011).

As we aimed to begin characterizing persistent foraging areas, we explored the overlap with phytoplankton biomass by superimposing the PVCs from kernel density estimation onto the satellite chlorophyll a concentrations (one possible predictor of seabird hotspots; Suryan et al. 2012). Standard monthly averaged MODIS-Aqua chlorophyll a concentrations, obtained from NASA's Goddard Space Flight Center, were used to construct a 6 month (July to December 2011) mean across the Benguela ecosystem. This period corresponded to the months over which the birds were tracked and was of sufficient length that the areas of persistence were not obscured by short-term variability.

\section{RESULTS}

Location data were received for a mean $( \pm \mathrm{SD})$ of 62 $\pm 41 \mathrm{~d}$ (Table 2). The penguins travelled at a mean speed of $34 \pm 17 \mathrm{~km} \mathrm{~d}^{-1}\left(1.4 \mathrm{~km} \mathrm{~h}^{-1}\right)$ to a mean maximum distance of $>1000 \mathrm{~km}$ from their release sites (Table 2). All 5 birds dispersed in a north-westerly 
Table 2. Spheniscus demersus. Summary of tracking dates and distances travelled for fledgling African penguins tracked in 2011. Maximum distance is the great circle route distance between the release location and the transmission most distant from the origin. Distance travelled is the cumulative distance covered between all validated locations (see 'Materials and methods')

\begin{tabular}{|cccccc|}
\hline PTT ID & $\begin{array}{c}\text { Release } \\
\text { date }\end{array}$ & $\begin{array}{c}\text { Last } \\
\text { transmission }\end{array}$ & $\begin{array}{c}\text { Days } \\
\text { at sea }\end{array}$ & $\begin{array}{c}\text { Maximum } \\
\text { distance }(\mathrm{km})\end{array}$ & $\begin{array}{c}\text { Distance } \\
\text { travelled }(\mathrm{km})\end{array}$ \\
\hline 105335 & 26 Jun & 23 Jul & 27 & 1466 & 1571 \\
105336 & 19 Jul & 25 Oct & 98 & 1461 & 2258 \\
105337 & 26 Jul & 25 Oct & 91 & 1334 & 2291 \\
105338 & 13 Sep & 6 Dec & 84 & 516 & 1628 \\
105339 & 13 Sep & 23 Sep & 10 & 339 & 446 \\
\hline
\end{tabular}

direction (Fig. 1A) and were between 106 and $357 \mathrm{~km}$ from their release sites after $6 \mathrm{~d}$. The 3 birds released near Robben Island travelled between 45 and $66 \mathrm{~km}$ $\mathrm{d}^{-1}$ (mean $=54.9 \pm 10.4 \mathrm{~km} \mathrm{~d}^{-1} ; 2.3 \mathrm{~km} \mathrm{~h}^{-1}$ ) during their initial $6 \mathrm{~d}$ at sea, while the 2 birds released at Stony Point moved 23 and $31 \mathrm{~km} \mathrm{~d}^{-1}$ over the same period $\left(\right.$ mean $\left.=27.0 \pm 5.7 \mathrm{~km} \mathrm{~d}^{-1} ; 1.1 \mathrm{~km} \mathrm{~h}^{-1}\right)$. The birds released near Robben Island initially travelled offshore to between the 200 and $1000 \mathrm{~m}$ isobaths. Bird 1 (PTT 105335) then remained close to or beyond the $200 \mathrm{~m}$ isobath until transmission ceased (Fig. 1A, Table 2), while the second (105336) and third birds (105337) moved inshore to the north of Lambert's Bay ( $32^{\circ} 05^{\prime} \mathrm{S}, 18^{\circ} 18^{\prime} \mathrm{E}$; Fig. 1$)$ and entered Namibia after 24 and $21 \mathrm{~d}$, respectively. Both birds remained $<100 \mathrm{~km}$ offshore and, in Namibia, predominately between Hollamsbird Island $\left(24^{\circ} 38^{\prime} \mathrm{S}\right.$, $\left.14^{\circ} 31^{\prime} \mathrm{E}\right)$ and Swakopmund $\left(22^{\circ} 41^{\prime} \mathrm{S}, 14^{\circ} 32^{\prime} \mathrm{E}\right.$; Fig. 1), until transmissions ceased (Fig. 1A). Birds 4 (105338) and 5 (105339) passed Cape Town close to the $200 \mathrm{~m}$ isobath. Bird 4 moved inshore and remained predominately between Lambert's Bay and Hondeklip Bay $\left(30^{\circ} 19^{\prime} \mathrm{S}, 17^{\circ} 16^{\prime} \mathrm{E}\right.$; Fig. 1) until transmissions ceased after $84 \mathrm{~d}$ (Fig. 1A, Table 2). Instrument 105339 failed $10 \mathrm{~d}$ after release (Table 2).

The kernel density analysis indicated two $50 \%$ PVCs (probable foraging areas), one encompassing Swakopmund and one south of Hondeklip Bay (Fig. 1B). Swakopmund is ca. $150 \mathrm{~km}$ north of Hollamsbird Island, the most northerly African penguin breeding colony, while the kernel in South Africa was ca. $200 \mathrm{~km}$ north of Marcus Island $\left(33^{\circ} 02^{\prime} \mathrm{S}\right.$, $17^{\circ} 58^{\prime} \mathrm{E}$ ), the nearest extant breeding colony (Crawford et al. 2011). Both $50 \%$ PVCs corresponded well to coastal areas where the 6 month mean chlorophyll a concentration was $>10 \mathrm{mg} \mathrm{m}^{-3}$, although the area of the highest concentration (south of Lambert's Bay) lay outside of the South African $50 \%$ PVC (Fig. 2).

\section{DISCUSSION}

African penguins are rarely sighted $>100 \mathrm{~km}$ from land (Wilson et al. 1988), but the movement offshore and to the north-west follows the prevailing ocean currents around Cape Town (Hutchings et al. 2009), suggesting that the birds initially allowed themselves to drift away from their release sites. Although they can only be determined with low precision from PTTs, the mean travel speeds observed over the first $6 \mathrm{~d}$ (1.1 and 2.3 $\mathrm{km} \mathrm{h}^{-1}$ ) are consistent with averages for breeding penguins drifting at the surface during foraging trips $\left(1.5 \mathrm{~km} \mathrm{~h}^{-1}\right.$ at night, $2.4 \mathrm{~km} \mathrm{~h}^{-1}$ during the day; Petersen et al. 2006). Many volant seabirds travel with prevailing winds on long-distance migrations (González-Solís et al. 2007), and

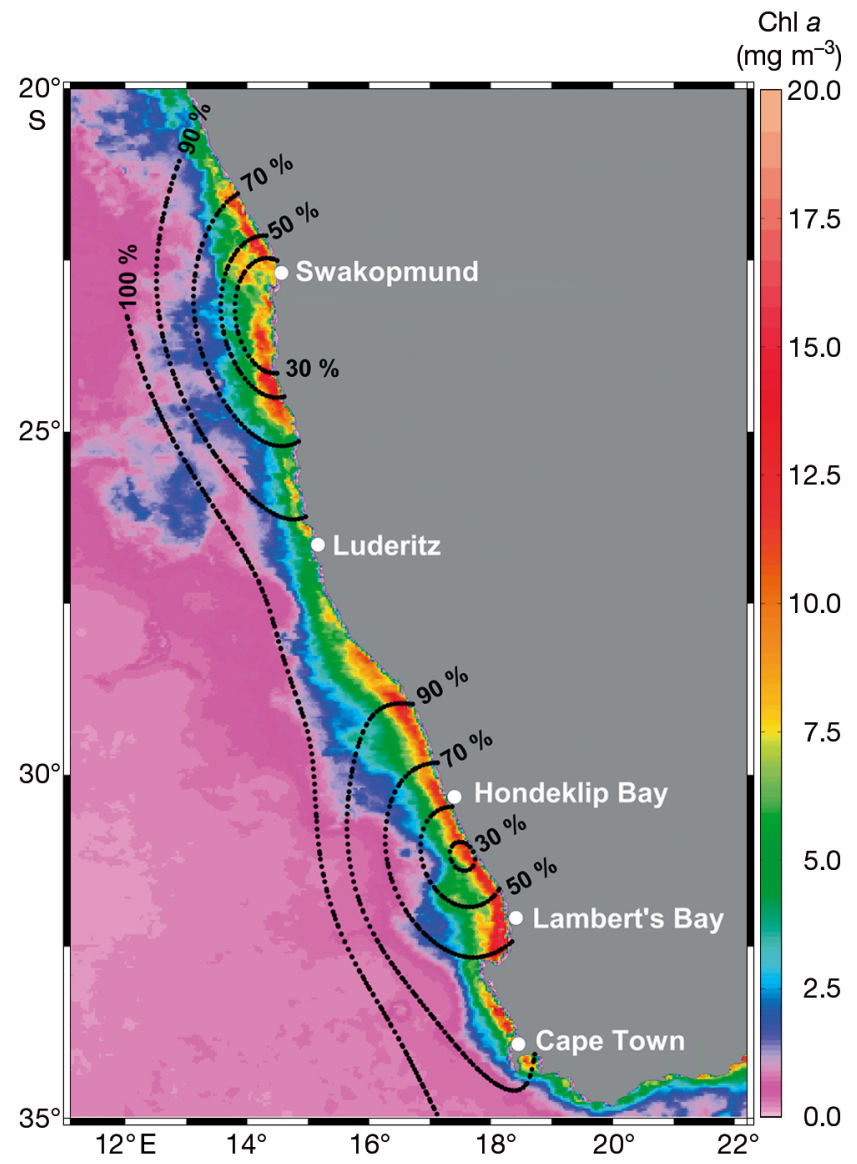

Fig. 2. Spheniscus demersus. The percentage volume contours from kernel density estimation based on the location data of 5 African penguin fledglings tracked from July to December 2011 using satellite transmitters (see Fig. 1) in relation to average chlorophyll a concentrations $\left(\mathrm{mg} \mathrm{m}^{-3}\right)$ for July to December 2011 
fledgling Adélie penguins Pygoscelis adeliae have been tracked moving away from their colonies on the prevailing current (Clarke et al. 2003). This may allow post-fledging seabirds to travel to areas associated with high prey availability with minimal energy investment, and, in species with no post-fledging parental care, there is little incentive to remain close to the natal colony at first. Little is known of the diet of post-fledging African penguins, but they cannot initially obtain the swimming speeds necessary to catch adult forage fish (Wilson 1985). Thus, they probably target sub-adult anchovy and sardine, the dominant prey of chick-rearing penguins (Crawford et al. 2011), but do not appear to gain experience by foraging in groups with adult birds and may be actively excluded from them (Ryan et al. 1987).

Moving offshore may also make a variety of other prey available to the fledglings. Anchovy prerecruits and several other pelagic fish species are common in waters between the 200 and $1000 \mathrm{~m}$ isobaths on South Africa's west coast (Pecquerie et al. 2004), the continental shelf edge is an important foraging ground for several pelagic seabird species (e.g. Petersen et al. 2008), and Bird 1 was beyond the $200 \mathrm{~m}$ isobath for at least $25 \mathrm{~d}$, thus presumably feeding. Isotopic segregation between breeding and immature seabirds has been observed for several species, including Magellanic penguins Spheniscus magellanicus (Forero et al. 2002), suggesting either distinct foraging areas or resource partitioning (e.g. Votier et al. 2011). Although the fledglings foraged predominately in coastal waters (Fig. 1), both 50\% PVCs were well outside of the foraging range of breeding adult African penguins (e.g. Petersen et al. 2006), suggesting that this species exploits distinct foraging areas during the life-cycle.

The areas denoted by the 50\% PVCs (Fig. 1B) correspond to regions associated with high primary production (Fig. 2), reliable zooplankton abundance and nursery grounds of small pelagic fish (Grémillet et al. 2008, Hutchings et al. 2009). The areas of low productivity around Lüderitz $\left(27^{\circ} \mathrm{S}\right)$ and of warmer sea-surface temperatures (SST) east of Cape Town (Hutchings et al. 2009) were generally avoided (Fig. 2). Oceanographic conditions (e.g. chlorophyll index and SST) can be good predictors of foraging areas of top predators (Suryan et al. 2012), but where ecosystems are under flux, spatial mismatches may occur between productivity and forage fish abundance (Grémillet et al. 2008). If so, the reduced hunting efficiency noted in fledgling seabirds (e.g. Wilson 1985) may well make them particularly susceptible to poor prey availability.
African penguin breeding populations at all South African colonies north of Cape Town continued to decline up to 2010, concurrent with an observed increase in adult mortality, whereas Stony Point, south-east of Cape Town, hosts the only penguin colony that maintained positive growth after 2000 . Altered prey availability following a decrease in the relative abundance of adult sardine and anchovy on the west coast compared to that east of Cape Agulhas $\left(20^{\circ} \mathrm{E}\right)$ is thought to be the primary driver of these trends (Crawford et al. 2011). So, while the areas utilized by the post-fledging penguins may have historically represented extremely profitable foraging grounds, present day movement onto South Africa's west coast and into Namibia (where African penguins rely on low-energy prey; Ludynia et al. 2010), suggests a minimal capacity for individual adaptation to local habitat degradation (e.g. Fort et al. 2012). This represents cause for concern, particularly as the situation in the Benguela may worsen over the next few decades, as future climate change scenarios predict changes in wind-driven upwelling, water temperature and productivity in the world's Eastern Boundary Current systems (Doney et al. 2012).

Globally, Marine Protected Areas (MPA) designated for seabirds have predominately focused on protecting breeding colonies (Lewison et al. 2012), and, in South Africa, the focus has been placed on understanding the impact of prey availability on breeding success and adult survival (e.g. Crawford et al. 2011, Sherley et al. 2013). Neither of the foraging areas identified here had any formal protection at the time of writing: the area offshore of Hondeklip Bay was utilized by the South African fishery (Pecquerie et al. 2004) and the Namibian Islands' MPA was defined by the range of breeding birds, thus only extended to $20 \mathrm{~km}$ north of Hollamsbird Island in 2012 (Ludynia et al. 2012a). Further studies are needed to determine whether the pattern of postfledging dispersal observed here is representative of seabirds in the Benguela ecosystem, and, given the likelihood that the PTTs increased the energetic cost of swimming and foraging for the birds equipped in this study (e.g. Wilson et al. 2004), our results should be considered with some caution as even short-term attachment of external devices can modify diving and foraging behaviour in penguins (e.g. Ludynia et al. 2012b). However, our data suggest the need to consider alternative management strategies (e.g. Ecosystems Approaches to Fisheries) to complement MPAs around breeding localities and for greater collaboration between countries in designing adaptive protection for key foraging hotspots (Yorio 2009, Fort 
et al. 2012, Lewison et al. 2012). Recruitment into the breeding population can have a critical impact on population dynamics; thus, gaining a better understanding of the areas used outside the breeding season by African penguins and other threatened seabirds should be afforded greater priority.

Acknowledgements. This study contributes to the African Penguin Chick Bolstering Project (South Africa) and the SEACODE research group (Namibia). The PTTs were funded by the Department of Environmental Affairs (DEA), and the project was supported by SANCCOB, the Bristol Conservation and Science Foundation, Overstrand Municipality, CapeNature and our institutes. The study was approved by DEA (RES2011/57), CapeNature (0035AAA008-00005) and the University of Cape Town's Animal Experimentation Committee (2011/V2/RS+LU). Bruce Dyer and Mike Meyer (DEA) assisted with PTT deployment and data acquisition. Nola Parsons (SANCCOB) provided additional information and veterinary supervision.

\section{LITERATURE CITED}

Barham PJ, Crawford RJM, Underhill LG, Wolfaardt AC and others (2006) Return to Robben Island of African penguins that were rehabilitated, relocated or reared in captivity following the Treasure oil spill of 2000. Ostrich 77: 202-209

> Barham PJ, Underhill LG, Crawford RJM, Altwegg R and others (2008) The efficacy of hand-rearing penguin chicks: evidence from African penguins (Spheniscus demersus) orphaned in the Treasure oil spill in 2000. Bird Conserv Int 18:144-152

> Clarke J, Kerry K, Fowler C, Lawless R, Eberhard S, Murphy R (2003) Post-fledging and winter migration of Adélie penguins Pygoscelis adeliae in the Mawson region of East Antarctica. Mar Ecol Prog Ser 248:267-278

Crawford RJM, Sabarros PS, Fairweather T, Underhill LG, Wolfaardt AC (2008) Implications for seabirds off South Africa of a long-term change in the distribution of sardine. Afr J Mar Sci 30:177-184

> Crawford RJM, Altwegg R, Barham BJ, Barham PJ and others (2011) Collapse of South Africa's penguins in the early 21st century. Afr J Mar Sci 33:139-156

> Croxall JP, Butchart SHM, Lascelles B, Stattersfield J, Sullivan B, Symes A, Taylor P (2012) Seabird conservation status, threats and priority actions: a global assessment. Bird Conserv Int 22:1-34

> Doney SC, Ruckelshaus M, Duffy JE, Barry JP and others (2012) Climate change impacts on marine ecosystems. Annu Rev Mar Sci 4:11-37

Forero MG, Hobson KA, Bortolotti GR, Donázar JA, Bertellotti M, Blanco G (2002) Food resource utilisation by the Magellanic penguin evaluated through stable-isotope analysis: segregation by sex and age and influence on offspring quality. Mar Ecol Prog Ser 234:289-299

Fort J, Pettex E, Tremblay Y, Lorentsen SH and others (2012) Meta-population evidence of oriented chain migration in northern gannets (Morus bassanus). Front Ecol Environ 10:237-242

Freitas C, Lydersen C, Fedak MA, Kovacs KM (2008) A simple new algorithm to filter marine mammal Argos loca- tions. Mar Mamm Sci 24:315-325

Conzález-Solís J, Croxall JP, Oro D, Ruiz X (2007) Transequatorial migration and mixing in the wintering areas of a pelagic seabird. Front Ecol Environ 5:297-301

> Grémillet D, Lewis S, Drapeau L, van der Lingen CD and others (2008) Spatial match-mismatch in the Benguela upwelling zone: Should we expect chlorophyll and seasurface temperature to predict marine predator distributions? J Appl Ecol 45:610-621

> Hart KM, Hyrenbach KD (2009) Satellite telemetry of marine megavertebrates: the coming of age of an experimental science. Endang Species Res 10:9-20

Hutchings L, van der Lingen CD, Shannon LJ, Crawford RJM and others (2009) The Benguela Current: an ecosystem of four components. Prog Oceanogr 83:15-32

Lewison R, Oro D, Godley BJ, Underhill L and others (2012) Research priorities for seabirds: improving conservation and management in the 21st century. Endang Species Res 17:93-121

> Ludynia K, Roux JP, Jones R, Kemper J, Underhill LG (2010) Surviving off junk: low-energy prey dominates the diet of African penguins Spheniscus demersus at Mercury Island, Namibia, between 1996 and 2009. Afr J Mar Sci 32:563-572

> Ludynia K, Kemper J, Roux JP (2012a) The Namibian Islands' Marine Protected Area: using seabird tracking data to define boundaries and assess their adequacy. Biol Conserv 156:136-145

Ludynia K, Dehnhard N, Poisbleau M, Demongin L, Masello JF, Quillfeldt P (2012b) Evaluating the impact of handling and logger attachment on foraging parameters and physiology in southern rockhopper penguins. PLoS ONE 7:e50429

Myers RA, Worm B (2003) Rapid worldwide depletion of predatory fish communities. Nature 423:280-283

> Pecquerie L, Drapeau L, Fréon P, Coetzee JC, Leslie RW, Griffiths MH (2004) Distribution patterns of key fish species of the southern Benguela ecosystem: an approach combining fishery-dependent and fishery-independent data. Afr J Mar Sci 26:115-139

Petersen SL, Ryan PG, Grémillet D (2006) Is food availability limiting African penguins Spheniscus demersus at Boulders? A comparison of foraging effort at mainland and island colonies. Ibis 148:14-26

> Petersen SL, Phillips RA, Ryan PG, Underhill LG (2008) Albatross overlap with fisheries in the Benguela Upwelling System: implications for conservation and management. Endang Species Res 5:117-127

Randall RM, Randall BM, Cooper J, La Cock GD, Ross GJB (1987) Jackass penguin Spheniscus demersus movements, inter-island visits, and settlement. J Field Ornithol 58:445-455

R Development Core Team (2011) R: a language and environment for statistical computing. R Foundation for Statistical Computing, Vienna. www.r-project.org

> Ryan PG, Wilson RP, Cooper J (1987) Intraspecific mimicry and status signals in juvenile African penguins. Behav Ecol Sociobiol 20:69-76

Sherley RB (2010) Factors influencing the demography of endangered seabirds at Robben Island, South Africa. $\mathrm{PhD}$ dissertation, University of Bristol

Sherley RB, Underhill LG, Barham BJ, Barham PJ and others (2013) Influence of local and regional prey availability on breeding performance of African penguins Spheniscus demersus. Mar Ecol Prog Ser 473:291-301 
Smith WHF, Sandwell DT (1997) Global seafloor topography from satellite altimetry and ship depth soundings. Science 277:1957-1962

Suryan RM, Santora JA, Sydeman WJ (2012) New approach for using remotely sensed chlorophyll a to identify seabird hotspots. Mar Ecol Prog Ser 451:213-225

van der Lingen CD, Shannon LJ, Cury P, Kreiner A, Moloney CL, Roux JP, Vaz-Velho F (2006) Resource and ecosystem variability, including regime shifts, in the Benguela current system. In: Shannon LV, Hempel G, Malanotte-Rizzoli P, Moloney C, Woods J (eds) Benguela - predicting a large marine ecosystem. Elsevier, Amsterdam

Votier SC, Birkhead TR, Oro D, Trinder M and others (2008) Recruitment and survival of immature seabirds in relation to oil spills and climate variability. J Anim Ecol 77: 974-983

Votier SC, Grecian WJ, Patrick S, Newton J (2011) Intercolony movements, at-sea behaviour and foraging in an

Editorial responsibility: Rory Wilson,

Swansea, UK immature seabird: results from GPS-PPT tracking, radiotracking and stable isotope analysis. Mar Biol 158: 355-362

Wilson RP (1985) The jackass penguin (Spheniscus demersus) as a pelagic predator. Mar Ecol Prog Ser 25:219-227

Wilson RP, Wilson MPT, Duffy DC (1988) Contemporary and historical patterns of African penguin Spheniscus demersus: distribution at sea. Estuar Coast Shelf Sci 26: 447-458

Wilson RP, Kreye JM, Lucke K, Urquhart H (2004) Antennae on transmitters on penguins: balancing energy budgets on the high wire. J Exp Biol 207:2649-2662

- Wood AG, Naef-Daenzer B, Prince PA, Croxall JP (2000) Quantifying habitat use in satellite-tracked pelagic seabirds: application of kernel estimation to albatross locations. J Avian Biol 31:278-286

> Yorio P (2009) Marine protected areas, spatial scales, and governance: implications for the conservation of breeding seabirds. Conserv Lett 2:171-178

Submitted: December 9, 2012; Accepted: March 23, 2013 Proofs received from author(s): June 18, 2013 